\title{
Brain atrophy in multiple sclerosis: therapeutic, cognitive and clinical impact
}

\author{
Atrofia cerebral en esclerosis múltiple: impacto clínico, cognitivo y terapéutico \\ Juan Ignacio Rojas, Liliana Patrucco, Jimena Miguez, Edgardo Cristiano
}

\begin{abstract}
Multiple sclerosis (MS) was always considered as a white matter inflammatory disease. Today, there is an important body of evidence that supports the hypothesis that gray matter involvement and the neurodegenerative mechanism are at least partially independent from inflammation. Gray matter atrophy develops faster than white matter atrophy, and predominates in the initial stages of the disease. The neurodegenerative mechanism creates permanent damage and correlates with physical and cognitive disability. In this review we describe the current available evidence regarding brain atrophy and its consequence in MS patients.
\end{abstract}

Keywords: multiple sclerosis, brain atrophy, neurodegeneration.

\section{RESUMEN}

La esclerosis múltiple (EM) fue considerada históricamente como una enfermedad inflamatoria de la sustancia blanca. Hoy en día hay mucha evidencia que apoya, además, el compromiso de la sustancia gris y los mecanismos neurodegenerativos, que son al menos parcialmente independientes de la inflamación. La atrofia de la sustancia gris se desarrolla más rápido que la atrofia de la sustancia blanca y predomina en las etapas iniciales de la enfermedad. El mecanismo neurodegenerativo, crea un daño permanente y se correlacionaría con la discapacidad física y cognitiva del paciente. En esta revisión, se describe la evidencia disponible actual con respecto a la atrofia cerebral y su consecuencia en los pacientes con EM.

Palabras-clave: esclerosis múltiple, atrofia cerebral, neurodegeneración.

Multiple sclerosis (MS) is recognized as an inflammatory and neurodegenerative disease of the central nervous system (CNS)1. Axonal degeneration is thought to be responsible for the irreversible progression of the disability seen in affected patients ${ }^{2,3,4}$. The loss of brain volume, or brain atrophy, has been classically considered as a marker present in severe or advanced stages of the disease $\mathrm{e}^{4}$. However, recent studies have demonstrated that this phenomenon also occurs in patients with clinically isolated syndromes suggestive of MS and also in the radiologically isolated syndrome $\mathrm{e}^{5,6}$.

In addition to these observations on disease progression and the course of atrophy in patients with MS, it is important to analyze the meaning that brain atrophy has in the clinical care of affected patients ${ }^{3}$.
In the present review, we aim to assess the existing techniques for measuring brain atrophy and the impact that it has on disease progression and on the physical and cognitive impairment of patients with MS.

\section{MOLECULAR BASES FOR AXONAL DEGENERATION IN MS}

The axonal transection was demonstrated in 1998 by Bruce Trapp et al., whom with confocal microscopy and tridimensional reconstructions could identify oval shape terminal axonal lesions in the MS plaques². The density of the damaged axons was $11.236 / \mathrm{mm}^{3}$ in active lesions, $3.138 / \mathrm{mm}^{3}$ in the edges of the chronic active hypercellular lesions and of $875 / \mathrm{mm}^{3}$ in the

Hospital Italiano Buenos Aires, Centro de Esclerosis Múltiple de Buenos Aires (CEMBA), Buenos Aires, Argentina.

Correspondence: Juan Ignacio Rojas; Center of multiple sclerosis of Buenos Aires (CEMBA), Italian Hospital of Buenos Aires; Gascón 450 C1181ACH Buenos Aires, Argentina; E-mail:juan.rojas@hospitalitaliano.org.ar

Conflicts of Interest: Juan Ignacio Rojas has received honoraria from Novartis as a scientific advisor. He has received travel grants and attended courses and conferences on behalf of Merck-Serono Argentina, Novartis Argentina.

Liliana Patrucco has received honoraria for scientific and research grants from Teva Tuteur, Merck Serono, Biogen Idec and Bayer Schering.

J. Miguez declares no conflict of interest.

Edgardo Cristiano has received fees for consultations as a scientific advisory board member and for travel to meetings, conferences and clinical trials of the following companies: Avanir, Bayer, Biogen, Merck, Novartis and Teva.

Received 28 June 2015; Received in final form 06 November 2015; Accepted 16 December 2015. 
hypocellular central areas of the chronic inactive lesions, thus being able to confirm that axonal loss correlates with the degree of inflammation in the disease, being present as from early stages of the disease ${ }^{2}$. Although the molecular mechanisms involved in the process of axonal damage are not exactly known, several hypothesis have been proposed ${ }^{7}$. It is known that myelin loss produces a failure in axonal action potential conduction, and this is sometimes seen from the clinical standpoint as neurologic deficit ${ }^{8}$. However, this axonal conduction can be recovered due to the expression and distribution of new sodium channels in the demyelinated axon, resulting in total or partial deficit remission ${ }^{8}$. This voltage - dependent sodium channels might probably play an important role in the neurodegenerative process seen in $\mathrm{MS}^{9}$. A consequence of axonal loss in a lesion is Wallerian degeneration along the fiber pathways that traverse it ${ }^{2}$. Axonal loss in lesions may therefore cause atrophy by two mechanisms: tissue loss within the lesion per se, and Wallerian degeneration in related fiber pathways. Given the large proportion that axons contribute to white matter volume, and evidence for considerable axonal damage in MS, axonal loss seems likely to be an important contributor to the atrophy observed in the disease $\mathrm{e}^{2,10,11}$.

\section{TECHNICAL CONSIDERATIONS IN BRAIN ATROPHY MEASUREMENT IN MS}

Currently, global and regional brain atrophy can be assessed using a wide variety of techniques, ${ }^{4,12,13,14}$. Some of these utilize manual methods for the quantitative analysis of the atrophy (such as bidimensional measurement of lateral ventricle diameter or of the third ventricle diameter, among others). Nevertheless, in spite of being simple and user friendly for an experienced operator, these methods carry important disadvantages because they not only require a prolonged analysis time but also demonstrate significant inter-observer variability ${ }^{14}$. As an alternative for this reproducibility hurdle, the automated segmentation techniques do not require interaction with the operator, they can process a larger number of images, and they eliminate the variability. The automation process of volumetric measurements has been possible because both MRI images (tridimensional sequences) and their processing through specific programs have improved ${ }^{4}$. These programs have allowed us to obtain more precise and reproducible measurements of brain atrophy in patients with MS. Automated or semi-automated measurement techniques can be divided in two groups: segmentation techniques (transversal) and registry techniques (longitudinal) $)^{4}$

\section{SEGMENTATION BASED TECHNIQUES (TRANSVERSAL)}

Segmentation based techniques (transversal) allow us to perform total brain volume measurements, either of white or gray matter, globally or regionally, in a certain time period ${ }^{4,14}$. One of the most commonly used techniques estimates brain parenchymal fraction (BPF), which is defined as the relationship between brain parenchyma volume and intra-cranial volume (obtained by the sum of the brain parenchyma and the cerebrospinal fluid (CSF)), or brain parenchyma/brain parenchyma $+\mathrm{CSF}^{15}$. The advantage of this technique is that both the brain parenchyma and the intra-cranial volume are measured in an automated fashion and skull size variability is considered for each patient separately.

\section{REGISTRY BASED TECHNIQUES (LONGITUDINAL)}

These registry based techniques allow us to perform longitudinal measurements of changes in brain atrophy ${ }^{4,14}$. The comparison of serial evaluations performed in a patient, or in a group of patients, quantifies changes that have occurred in brain volume during a certain time-frame. These techniques, which are largely automated, express results as a percentage of change in brain volume 4 . In Table 1 commonly techniques used for the measurement of brain atrophy can be seen, together with their main limitations and characteristics.

\section{BRAIN ATROPHY AND THE EXISTING EVIDENCE CONCERNING ITS MEANING}

\section{Brain atrophy and the risk of disease progression}

We have thoroughly evaluated the role of brain atrophy as a prognostic factor in the progression of the disease. As previously mentioned, brain atrophy is detected in the early stages of the disease, even in stages without clinical symptoms ${ }^{16,17}$. It has already been demonstrated that the rate of brain atrophy is greater in patients with a clinically isolated syndrome (CIS) that progresses to MS when compared with patients that do not worsen during the course of their disease. This impacts the early prognosis of the disease ${ }^{18}$. A sub-analysis from the ETOMS study that assessed the efficacy of [sc] interferon beta 1-a sc in patients with CIS showed a significant difference in mean annual percentage brain volume change (PBVC) between patients who had disease progression and those who did not $(-0.92 \%$ and $-0.56 \%$, respectively $)^{19}$. Similar findings were identified in an observational study done by Pérez-Miralles et al. ${ }^{5}$ which showed a greater decrease of PBVC in 176 patients with CIS who progressed to MS when compared to those patients who did not progress $(-0.65 \%$ compared to $+0.059 \%, \mathrm{p}<0.001)$. These findings established a prognostic role for brain atrophy and MS conversion in patients who had a first demyelinating event. Di Filippo et al. ${ }^{18}$ also demonstrated the prognostic role of brain atrophy and the risk of progression to MS after a first clinical event. In their studies, those patients with CIS that progressed to MS during a 6 year follow-up had an atrophy rate of $0.5 \%$ vs. $-0.2 \%$ of those who did not, thereby making this an important prognostic factor for MS conversion ${ }^{18}$ (Figures 1 and 2). 


\section{CLINICAL IMPACT OF BRAIN ATROPHY IN PATIENTS WITH MS}

A study from Fisher et al. ${ }^{20}$ published in 2002 showed the relationship between brain atrophy and physical impairment during an 8-year follow-up. This study also stated that brain atrophy had a clinical impact: worsening expanded disability status scale (EDSS) and progression to disability. A correlation between atrophy rate and physical disability was performed and suggesting that progression to atrophy in relapsing remitting multiple sclerosis (RRMS) was clinically relevant and may be a useful marker to predict disease progression ${ }^{20}$. Following this line of research,
Fisniku et al. ${ }^{21}$ evaluated whether physical disability during follow-up was related to white and gray matter brain atrophy. The study included 73 patients with CIS who were followed up for almost 20 years showed that atrophy of gray matter was related to an increase in EDSS $(p<0.001)$ and a worsening in the functional assessment of the patients $(\mathrm{p}<0.001)$ in a higher proportion than in the atrophy of the white matter ${ }^{21}$. Sailer et al. ${ }^{22}$ identified that a greater thinning of the global cortical thickness, and specially the motor cortex, related to worse performance in physical assessment and an increase in EDSS ( $p=0.001)$ during follow-up in patients with MS. These studies support the finding that more significant brain atrophy correlates with a worsening of physical

Table 1. Techniques used to measure brain atrophy.

\begin{tabular}{|c|c|c|c|}
\hline Technique & $\begin{array}{l}\text { Degree of } \\
\text { automation }\end{array}$ & Characteristics & Limitations \\
\hline $\begin{array}{l}\text { BSI } \\
\text { www.sourceforge.net/projects/bsintegral/ }\end{array}$ & Semi-automated & $\begin{array}{c}\text { Measures changes in brain volume using } \\
\text { pairs of images }\end{array}$ & $\begin{array}{l}\text { Does not distinguish } \\
\text { between brain tissue }\end{array}$ \\
\hline $\begin{array}{l}\text { FIRST } \\
\text { http://fsl.fmrib.ox.ac.uk/fsl/fslwiki/ }\end{array}$ & Automated & Volumetry and analysis of deep gray matter & $\begin{array}{l}\text { Analysis in a certain time } \\
\text { point }\end{array}$ \\
\hline $\begin{array}{l}\text { FreeSurfer } \\
\text { http://freesurfer.net/ }\end{array}$ & $\begin{array}{l}\text { Automated or } \\
\text { manual }\end{array}$ & $\begin{array}{c}\text { Volumetry of deep gray matter; cortical } \\
\text { thickness; simultaneous analysis in multiple } \\
\text { time points }\end{array}$ & $\begin{array}{l}\text { Prolonged calculation } \\
\text { time needed }\end{array}$ \\
\hline $\begin{array}{l}\text { Nifty-Seg } \\
\text { http://cmic.cs.ucl.ac.uk/home/software/ }\end{array}$ & Automated & Measures cortical thickness & $\begin{array}{c}\text { Analysis in a certain time } \\
\text { point }\end{array}$ \\
\hline $\begin{array}{l}\text { SepINRIA } \\
\text { http://www-sop.inria.fr/asclepios/software/ } \\
\text { SepINRIA/ }\end{array}$ & Automated & $\begin{array}{l}\text { Measures changes in brain volume using } \\
\text { pairs of images }\end{array}$ & $\begin{array}{l}\text { Does not distinguish } \\
\text { between brain tissues }\end{array}$ \\
\hline $\begin{array}{l}\text { SIENA } \\
\text { http://fsl.fmrib.ox.ac.uk/fsl/fslwiki/ }\end{array}$ & Automated & $\begin{array}{c}\text { Measures changes in brain volume using } \\
\text { pairs of images }\end{array}$ & $\begin{array}{l}\text { Does not distinguish } \\
\text { between brain tissues }\end{array}$ \\
\hline $\begin{array}{l}\text { SIENA-R } \\
\text { http://fsl.fmrib.ox.ac.uk/fsl/fslwiki/ }\end{array}$ & Automated & $\begin{array}{c}\text { Analysis of brain focal atrophy in groups of } \\
\text { patients using pairs of images }\end{array}$ & $\begin{array}{l}\text { Does not distinguish } \\
\text { between brain tissues }\end{array}$ \\
\hline $\begin{array}{l}\text { SPM-Longitudinal VBM } \\
\text { www.fil.ion.ucl.ac.uk/spm/ }\end{array}$ & Automated & $\begin{array}{c}\text { Analysis of brain focal atrophy in groups of } \\
\text { patients using pairs of images }\end{array}$ & $\begin{array}{l}\text { Can only be applied in a } \\
\text { group }\end{array}$ \\
\hline $\begin{array}{l}\text { TOADS-CRUISE } \\
\text { wWw.nitrc.org/projects/toads-cruise/ }\end{array}$ & Automated & Measurement of cortical thickness changes & - \\
\hline
\end{tabular}

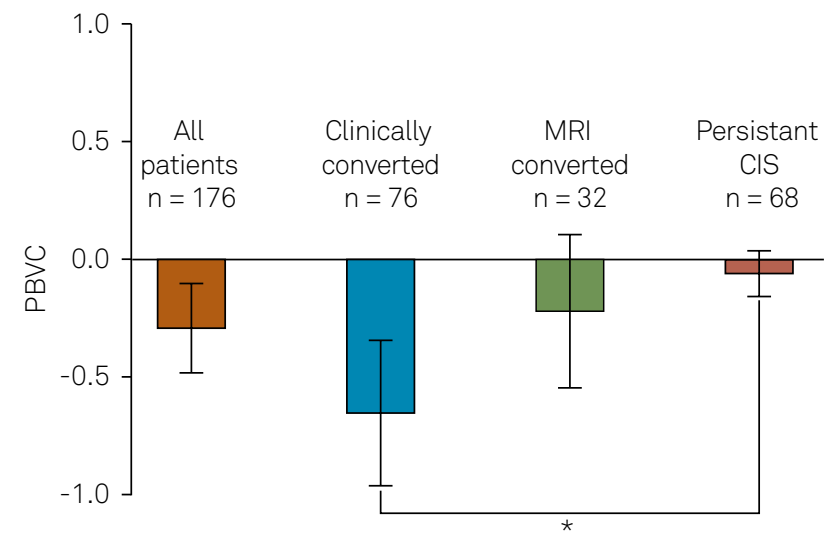

PBVC: percentage brain volume change; CIS: clinically isolated syndrome.

Figure 1. Percentage of brain volume change and prediction of multiple sclerosis (MS) conversion in patients with CIS. In this study, those patients with greater atrophy rate after diagnosis presented a higher risk of MS conversion, defined either clinically or by images during follow-up ${ }^{5}$.

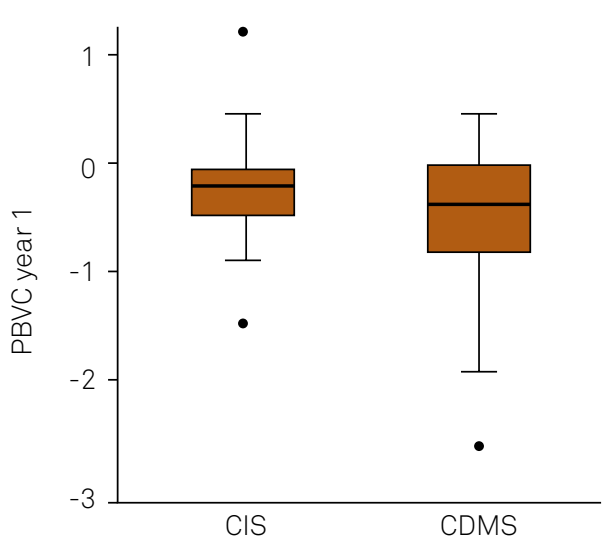

PBVC: percentage brain volume change; CIS: clinically isolated syndrome; CDMS: clinically definity multiple sclerosis.

Figure 2. Box plots that show in another study the risk of multiple sclerosis (MS) conversion during follow-up in patients with CIS. Higher atrophy during the first year of disease implies a greater risk ${ }^{18}$. 
disability in patients with MS. The remainder of the evidence concerning this issue is explained in detail in Table 2.

\section{BRAIN ATROPHY AND COGNITIVE IMPACT IN MS PATIENTS}

The impact of brain atrophy in the cognitive field can be seen as from the pre-morbid stage of the disease, known as the radiologic isolated syndrome (RIS) ${ }^{16}$. Amato et al. reported that $27.6 \%$ of these patients had signs of cognitive deterioration and that cortical brain volume reduction related to a worse performance in cognitive tests $(p=0.043)^{35}$. In patients with RRMS, the finding of regional atrophy has been related to specific functional involvement. For example, atrophy of the corpus callosum (CC) has been related to a worsening in verbal fluency tests as well as in attention tests, as measured by the Symbol Digit Modality Test

Table 2. Brain atrophy in multiple sclerosis (MS): prognostic factor and impact on physical disability in patients with clinically isolated syndrome (CIS) and MS.

\begin{tabular}{|c|c|c|c|c|c|}
\hline Author & Aim of the study & $\mathrm{N}$ patients & Result variable & $\begin{array}{l}\text { Brain atrophy measurement } \\
\text { (software used) }\end{array}$ & Comment \\
\hline $\begin{array}{l}\text { Jacobsen } \\
\text { et al. }{ }^{23}\end{array}$ & $\begin{array}{l}\text { Assess atrophy as marker } \\
\text { of progression of physical } \\
\text { disability in 5-10 year } \\
\text { follow up }\end{array}$ & $\begin{array}{l}81 \text { with } \\
\text { MS }\end{array}$ & $\begin{array}{l}\text { Disease progression } \\
\text { measured by EDSS }\end{array}$ & $\begin{array}{l}\text { Longitudinal PBVC and } \\
\text { tissue specific transversal } \\
\text { volumes changes } \\
\text { (SIENA, SIENAX y FIRST) }\end{array}$ & $\begin{array}{c}\text { Patients with disability progression } \\
\text { have more putaminal and cortical } \\
\text { brain atrophy }\end{array}$ \\
\hline $\begin{array}{l}\text { Hofstetter } \\
\text { et al. }{ }^{24}\end{array}$ & $\begin{array}{l}\text { Assess gray matter } \\
\text { changes as a marker of } \\
\text { disability progression. }\end{array}$ & $\begin{array}{l}239 \text { with } \\
\text { MS }\end{array}$ & $\begin{array}{l}\text { EDSS progression } \\
\text { and MSFC } \\
\text { worsening }\end{array}$ & $\begin{array}{l}\text { Longitudinal changes in gray } \\
\text { matter (VBM SPM5) }\end{array}$ & $\begin{array}{l}\text { Physical disability was associated with } \\
\text { greater gray matter atrophy }\end{array}$ \\
\hline $\begin{array}{l}\text { Pérez- } \\
\text { Miralles } \\
\text { et al. }{ }^{5}\end{array}$ & $\begin{array}{l}\text { Evaluate brain atrophy as } \\
\text { prognostic factor in CIS }\end{array}$ & $\begin{array}{l}176 \text { with } \\
\text { CIS }\end{array}$ & $\begin{array}{l}\text { MS conversion in } \\
\text { patients with CIS }\end{array}$ & Changes in PBVC (SIENA) & $\begin{array}{c}\text { The decrease in global brain volume } \\
\text { foresaw MS conversion in patients } \\
\text { with CIS }\end{array}$ \\
\hline $\begin{array}{l}\text { Zivadinov } \\
\text { et al. }{ }^{25}\end{array}$ & $\begin{array}{l}\text { Assess atrophy of the } \\
\text { thalamus as prognostic } \\
\text { factor in CIS }\end{array}$ & $\begin{array}{l}216 \text { with } \\
\text { CIS }\end{array}$ & $\begin{array}{l}\text { Conversion to MS in } \\
\text { patients with } \mathrm{CIS}\end{array}$ & $\begin{array}{l}\text { PBVC and subcortical } \\
\text { structures changes } \\
\text { (SIENA y FIRST) }\end{array}$ & $\begin{array}{l}\text { Atrophy of the thalamus and of global } \\
\text { brain structures was associated with } \\
\text { an increase in the risk of conversion to } \\
\text { MS in patients with CIS }\end{array}$ \\
\hline $\begin{array}{l}\text { Popescu } \\
\text { et al. }{ }^{26}\end{array}$ & $\begin{array}{l}\text { Evaluate whether brain } \\
\text { atrophy predicts physical } \\
\text { disability in a } 10 \text { year } \\
\text { follow up period }\end{array}$ & $\begin{array}{l}261 \text { with } \\
\text { MS }\end{array}$ & $\begin{array}{c}\text { Disability } \\
\text { progression } \\
\text { quantified by EDSS }\end{array}$ & $\begin{array}{c}\text { PBVC longitudinal } \\
\text { changes and transversal } \\
\text { measurements } \\
\text { (SIENA/SIENAX) }\end{array}$ & $\begin{array}{l}\text { Brain atrophy might play a significant } \\
\text { role in predicting long term disability in } \\
\text { patients with MS }\end{array}$ \\
\hline $\begin{array}{l}\text { Rojas } \\
\text { et al. }{ }^{27}\end{array}$ & $\begin{array}{l}\text { Assess if brain atrophy } \\
\text { predicts physical disability } \\
\text { in a } 7 \text { year follow up period. }\end{array}$ & $\begin{array}{l}26 \text { with } \\
\text { RRMS }\end{array}$ & $\begin{array}{l}\text { Physical disability } \\
\text { progression } \\
\text { measured by EDSS }\end{array}$ & $\begin{array}{l}\text { PBVC longitudinal changes } \\
\text { (SIENA) }\end{array}$ & $\begin{array}{l}\text { Greater brain atrophy during the early } \\
\text { stages of the disease was associated with } \\
\text { greater physical disability during follow up }\end{array}$ \\
\hline $\begin{array}{l}\text { Di Filippo } \\
\text { et al. }{ }^{18}\end{array}$ & $\begin{array}{l}\text { Evaluate if brain atrophy } \\
\text { during the first year of } \\
\text { CIS predicted the clinical } \\
\text { status at } 6 \text { year follow up }\end{array}$ & 99 with CIS & $\begin{array}{l}\text { Physical disability } \\
\text { progression } \\
\text { measured by EDSS } \\
\text { and MS conversion }\end{array}$ & $\begin{array}{l}\text { Longitudinal changes in } \\
\text { PBVC (SIENA) }\end{array}$ & $\begin{array}{l}\text { Brain atrophy was associated with MS } \\
\text { conversion in patients with CIS, and not } \\
\text { with physical disability during follow up }\end{array}$ \\
\hline $\begin{array}{l}\text { Lukas } \\
\text { et al. }{ }^{28}\end{array}$ & $\begin{array}{l}\text { Assess the predictive } \\
\text { value of central atrophy } \\
\text { in relation to the risk of } \\
\text { physical impairment in } \\
\text { early stages of the disease }\end{array}$ & 54 with MS & $\begin{array}{l}\text { Physical disability } \\
\text { progression } \\
\text { measured by EDSS }\end{array}$ & $\begin{array}{c}\text { PBVC and PVVC longitudinal } \\
\text { changes (SIENA) }\end{array}$ & $\begin{array}{c}\text { Greater PVVC reduction was the } \\
\text { physical disability predictor factor in } \\
\text { the mean term }\end{array}$ \\
\hline $\begin{array}{l}\text { Horakova } \\
\text { et al. }{ }^{29}\end{array}$ & $\begin{array}{l}\text { Evaluate the predictive value } \\
\text { of gray and white matter } \\
\text { atrophy in physical disability }\end{array}$ & $\begin{array}{l}181 \text { with } \\
\text { RRMS }\end{array}$ & $\begin{array}{l}\text { Physical disability } \\
\text { progression } \\
\text { measured by EDSS }\end{array}$ & $\begin{array}{l}\text { Longitudinal and transversal } \\
\text { PBVC changes (SIENA y } \\
\text { SIENAX) }\end{array}$ & $\begin{array}{c}\text { Decrease in total brain and gray matter } \\
\text { volume was associated with greater } \\
\text { physical deterioration }\end{array}$ \\
\hline $\begin{array}{l}\text { Fisher } \\
\text { et al. }^{30}\end{array}$ & $\begin{array}{l}\text { Assess the impact of } \\
\text { gray matter atrophy in } \\
\text { physical disability }\end{array}$ & $70 \mathrm{MS}$ & $\begin{array}{c}\text { Disability } \\
\text { progression } \\
\text { measured by EDSS }\end{array}$ & $\begin{array}{l}\text { Measurement of segmental } \\
\text { volumes (BPF ad. Hoc } \\
\text { software Cleveland Clinic) }\end{array}$ & $\begin{array}{l}\text { Gray matter atrophy related with more } \\
\text { physical impairment during follow up }\end{array}$ \\
\hline $\begin{array}{l}\text { Fisniku } \\
\text { et al. }{ }^{21}\end{array}$ & $\begin{array}{l}\text { Correlation between } \\
\text { brain atrophy and } \\
\text { physical disability }\end{array}$ & $\begin{array}{l}73 \text { with CIS } \\
\text { followed for } \\
20 \text { years }\end{array}$ & $\begin{array}{l}\text { Physical disability } \\
\text { measured by EDSS }\end{array}$ & $\begin{array}{l}\text { Segmental volumes } \\
\text { measurements } \\
\text { (SIENAX y VBM-SPM2) }\end{array}$ & $\begin{array}{l}\text { Gray matter atrophy correlated with } \\
\text { more physical disability in a } 20 \text { year } \\
\text { follow up }\end{array}$ \\
\hline $\begin{array}{l}\text { Jasperse } \\
\text { et al. }{ }^{31}\end{array}$ & $\begin{array}{l}\text { Evaluate the correlation } \\
\text { between brain volume } \\
\text { changes and physical and } \\
\text { cognitive disability }\end{array}$ & $\begin{array}{l}79 \text { with } \\
\text { MS }\end{array}$ & $\begin{array}{l}\text { Physical disability } \\
\text { measured by EDSS, } \\
\text { changes in MSFC }\end{array}$ & $\begin{array}{l}\text { Regional changes in brain } \\
\text { volume and PBVC (SIENA) }\end{array}$ & $\begin{array}{l}\text { Central atrophy implied more physical } \\
\text { disability, whereas involvement of } \\
\text { complex functions correlated with } \\
\text { central and peripheral atrophy }\end{array}$ \\
\hline $\begin{array}{l}\text { Charil } \\
\text { et al. }{ }^{32}\end{array}$ & $\begin{array}{c}\text { Cortical atrophy relates } \\
\text { to physical disability } \\
\text { progression }\end{array}$ & $\begin{array}{l}425 \text { with } \\
\text { MS }\end{array}$ & $\begin{array}{l}\text { Physical disability } \\
\text { progression } \\
\text { measured by EDSS }\end{array}$ & $\begin{array}{l}\text { Segmental cortical atrophy } \\
\text { (INSECT software) }\end{array}$ & $\begin{array}{c}\text { Atrophy of interconnected areas of the } \\
\text { brain might be associated with motor } \\
\text { disability in involved patients }\end{array}$ \\
\hline $\begin{array}{l}\text { Turner } \\
\text { et al. }{ }^{33}\end{array}$ & $\begin{array}{l}\text { Assess the correlation } \\
\text { between changes in brain } \\
\text { volume and physical } \\
\text { disability after } 4 \text { years. }\end{array}$ & 38 with MS & $\begin{array}{l}\text { Physical disability } \\
\text { progression } \\
\text { measured by EDSS }\end{array}$ & $\begin{array}{l}\text { Changes in PBVC and in } \\
\text { ventricular volume }\end{array}$ & $\begin{array}{c}\text { More significant brain atrophy during } \\
\text { follow up correlated with more } \\
\text { physical disability }\end{array}$ \\
\hline $\begin{array}{l}\text { Bakshi } \\
\text { et al. }{ }^{34}\end{array}$ & $\begin{array}{l}\text { Evaluate the correlation of } \\
\text { changes in brain volume } \\
\text { with physical disability }\end{array}$ & $\begin{array}{l}149 \text { with } \\
\text { MS }\end{array}$ & $\begin{array}{l}\text { Physical disability } \\
\text { progression } \\
\text { measured EDSS }\end{array}$ & Regional atrophy (BPF). & $\begin{array}{l}\text { Brain atrophy related to physical } \\
\text { worsening in patients with severe } \\
\text { involvement }\end{array}$ \\
\hline
\end{tabular}

EDSS: expanded disability status scale; PBVC: percentage brain volume change; MSFC: multiple sclerosis functional composite; RRMS: relapsing remitting multiple sclerosis. 
(SDMT) and the PASAT test. Atrophy of the anterior segment of the CC has been related to fatigue and its degree of severity ${ }^{36}$. Likewise, Rudick et al. ${ }^{37}$ showed a correlation between gray matter atrophy progression and worsening of the MSFC. Table 3 shows the evidence that impact atrophy has on the cognitive field.

Table 3. Brain atrophy in MS and its impact on cognition and fatigue.

\begin{tabular}{|c|c|c|c|c|c|}
\hline Author & Aim of the study & $\begin{array}{l}N \text { patients } \\
\text { with RMMS }\end{array}$ & Result variable & $\begin{array}{c}\text { Brain atrophy } \\
\text { measurement } \\
\text { (software used) }\end{array}$ & Comment \\
\hline $\begin{array}{l}\text { Cruz } \\
\text { Gómez } \\
\text { et al. }{ }^{38}\end{array}$ & $\begin{array}{l}\text { Correlation between brain } \\
\text { atrophy and fatigue }\end{array}$ & 60 & $\begin{array}{l}\text { Fatigue measured by } \\
\text { fatigue severity scale }\end{array}$ & $\begin{array}{l}\text { Segmental atrophy by } \\
\text { VBM-SPM8 }\end{array}$ & $\begin{array}{l}\text { In patients with fatigue there was } \\
\text { a reduction in segmentary gray } \\
\text { and white matter volume when } \\
\text { compared to controls }\end{array}$ \\
\hline $\begin{array}{l}\text { Amato } \\
\text { et al. } .^{39}\end{array}$ & $\begin{array}{c}\text { Evaluate the relationship } \\
\text { between cognitive reserve and } \\
\text { brain atrophy in patients with } \\
\text { RRMS }\end{array}$ & 52 & $\begin{array}{l}\text { Cognitive reserve was } \\
\text { assessed through a } \\
\text { score that included } \\
\text { education, } I Q \text { and pre } \\
\text { morbid activities }\end{array}$ & $\begin{array}{l}\text { Segmental brain volumes } \\
\text { and longitudinal PBVC } \\
\text { changes (SIENAX } \\
\text { and SIENA) }\end{array}$ & $\begin{array}{c}\text { The cognitive reserve might } \\
\text { compensate structural damage, } \\
\text { however, with damage and atrophy } \\
\text { progression, this compensation } \\
\text { is lost }\end{array}$ \\
\hline $\begin{array}{l}\text { Batista } \\
\text { et al. } .0\end{array}$ & $\begin{array}{l}\text { Determine if atrophy of the } \\
\text { thalamus and basal ganglia play } \\
\text { a role in the speed to process } \\
\text { information in RRMS (SPI) }\end{array}$ & 86 & $\begin{array}{l}\text { Complete } \\
\text { neuropsychologic } \\
\text { tests, PASAT and } \\
\text { SDMT. }\end{array}$ & $\begin{array}{l}\text { Segmentary subcortical } \\
\text { subglobal volumes } \\
\text { (SIENAX and FIRST) }\end{array}$ & $\begin{array}{l}\text { Information processing alterations } \\
\text { was related to greater atrophy of } \\
\text { subcortical structures that include } \\
\text { the thalamus and the caudate }\end{array}$ \\
\hline $\begin{array}{l}\text { Calabrese } \\
\text { et al. } .^{11}\end{array}$ & $\begin{array}{l}\text { Evaluate if atrophy of cortical } \\
\text { and deep gray matter structures } \\
\text { relates to fatigue in patients with } \\
\text { RRMS }\end{array}$ & 152 & $\begin{array}{l}\text { Fatigue measured by } \\
\text { the fatigue impact } \\
\text { scale }\end{array}$ & $\begin{array}{l}\text { Segmental subcortical } \\
\text { volumes (FreeSurfer) }\end{array}$ & $\begin{array}{l}\text { Segmental atrophies were related to } \\
\text { greater fatigue in RRMS }\end{array}$ \\
\hline $\begin{array}{l}\text { Pellicano } \\
\text { et al. } 42\end{array}$ & $\begin{array}{c}\text { Assess the correlation between } \\
\text { cortical and subcortical regional } \\
\text { atrophy in RRMS. }\end{array}$ & 24 & $\begin{array}{l}\text { Fatige measured by } \\
\text { the fatigue impact } \\
\text { scale }\end{array}$ & $\begin{array}{l}\text { Cortical and subcortical } \\
\text { segmental brain atrophy } \\
\text { (FreeSurfer) }\end{array}$ & $\begin{array}{l}\text { Parietal cortex atrophy was } \\
\text { significantly related to fatigue in } \\
\text { patients with RRMS }\end{array}$ \\
\hline $\begin{array}{l}\text { Sumowski } \\
\text { et al. }{ }^{43}\end{array}$ & $\begin{array}{l}\text { Evaluate the effect of brain } \\
\text { atrophy on the cognitive reserve }\end{array}$ & 38 & Information processing & $\begin{array}{l}\text { Third ventricle enlargement } \\
\text { (manual processing) }\end{array}$ & $\begin{array}{l}\text { Brain atrophy showed negative } \\
\text { effects on information processing } \\
\text { that was partially attenuated by the } \\
\text { cognitive reserve }\end{array}$ \\
\hline $\begin{array}{l}\text { Mineev } \\
\text { et al. } .44\end{array}$ & $\begin{array}{c}\text { Assess correlation between } \\
\text { cognitive deterioration and brain } \\
\text { atrophy }\end{array}$ & 65 & $\begin{array}{l}\text { Extended } \\
\text { neuropsychologic } \\
\text { assessment }\end{array}$ & $\begin{array}{l}\text { Manually measured brain } \\
\text { volumes }\end{array}$ & $\begin{array}{c}\text { Greater brain atrophy correlated } \\
\text { with greater cognitive involvement in } \\
\text { patients with RRMS }\end{array}$ \\
\hline $\begin{array}{l}\text { Sanchez } \\
\text { et al. } 45\end{array}$ & $\begin{array}{c}\text { Evaluate the correlation } \\
\text { between brain atrophy and } \\
\text { cognitive deterioration in RRMS }\end{array}$ & 52 & $\begin{array}{l}\text { Extended } \\
\text { neuropsychologic } \\
\text { assessment. }\end{array}$ & $\begin{array}{l}\text { Subcortical global and } \\
\text { segmental atrophy } \\
\text { (manual processing of the } \\
\text { bicaudate space and of the } \\
\text { third ventricle diameter) }\end{array}$ & $\begin{array}{l}\text { Central ventricle atrophy was the } \\
\text { best predictor for global cognitive } \\
\text { deterioration in this group of } \\
\text { patients with RRMS }\end{array}$ \\
\hline $\begin{array}{l}\text { Houtchens } \\
\text { et al. }{ }^{46}\end{array}$ & $\begin{array}{l}\text { Assess if thalamic atrophy } \\
\text { correlates with cognitive } \\
\text { deterioration in RRMS }\end{array}$ & 79 & $\begin{array}{l}\text { Extended } \\
\text { neuropsychologic } \\
\text { assessment. }\end{array}$ & $\begin{array}{l}\text { BPF and subcortical } \\
\text { brain volumes using JIM } \\
\text { software }\end{array}$ & $\begin{array}{c}\text { Thalamic atrophy might } \\
\text { be a sensitive biomarker } \\
\text { of neurodegeneration and } \\
\text { cognitive impact }\end{array}$ \\
\hline $\begin{array}{l}\text { Tekok-Kilic } \\
\text { et al. }{ }^{47}\end{array}$ & $\begin{array}{c}\text { Evaluate the correlation } \\
\text { between gray matter atrophy } \\
\text { and cognitive involvement in } \\
\text { RRMS }\end{array}$ & 59 & $\begin{array}{l}\text { Extended } \\
\text { neuropsychologic } \\
\text { assessment. }\end{array}$ & $\begin{array}{l}\text { Brain segmental volumetry } \\
\text { (SABRE software) }\end{array}$ & $\begin{array}{c}\text { Thalamic atrophy might } \\
\text { be a sensitive biomarker } \\
\text { of neurodegeneration and } \\
\text { cognitive impact }\end{array}$ \\
\hline $\begin{array}{l}\text { Tedeschi } \\
\text { et al. } 48\end{array}$ & $\begin{array}{c}\text { Assess the correlation of } \\
\text { fatigue with white and gray } \\
\text { matter atrophy }\end{array}$ & 222 & $\begin{array}{l}\text { Fatige measured by } \\
\text { the fatigue impact } \\
\text { scale }\end{array}$ & $\begin{array}{c}\text { Brain total and segmental } \\
\text { volumes }\end{array}$ & $\begin{array}{l}\text { Greater fatigue was observed with } \\
\text { greater brain atrophy }\end{array}$ \\
\hline $\begin{array}{l}\text { Sanfilipo } \\
\text { et al. } 49\end{array}$ & $\begin{array}{l}\text { Evaluate correlation of gray } \\
\text { and white matter atrophy with } \\
\text { cognitive deterioration in RRMS }\end{array}$ & 40 & $\begin{array}{l}\text { Extended } \\
\text { neuropsychologic } \\
\text { assessment }\end{array}$ & $\begin{array}{l}\text { Cortical and subcortical } \\
\text { brain total and segmental } \\
\text { volumes (SPM99) }\end{array}$ & $\begin{array}{l}\text { Gray and white matter atrophy } \\
\text { contribute independently to } \\
\text { cognitive deterioration in RRMS }\end{array}$ \\
\hline $\begin{array}{l}\text { Lazeron } \\
\text { et al. }{ }^{.0}\end{array}$ & $\begin{array}{l}\text { Assess the correlation between } \\
\text { brain atrophy and cognitive } \\
\text { deterioration in RRMS }\end{array}$ & 82 & Rao short battery tests & $\begin{array}{l}\text { Segmental and total } \\
\text { brain volume (BPF } \\
\text { local software) }\end{array}$ & $\begin{array}{l}\text { Cognitive deterioration in MS } \\
\text { depends moderately on brain } \\
\text { structural damage }\end{array}$ \\
\hline $\begin{array}{l}\text { Edwards } \\
\text { et al. }^{51}\end{array}$ & $\begin{array}{c}\text { Evaluate the association } \\
\text { between cognitive deterioration } \\
\text { and supra - tentorial } \\
\text { brain atrophy. }\end{array}$ & 40 & $\begin{array}{l}\text { Extended } \\
\text { neuropsychologic } \\
\text { assessment }\end{array}$ & $\begin{array}{c}\text { Segmental and total brain } \\
\text { volume (BPF) }\end{array}$ & $\begin{array}{c}\text { White matter atrophy correlated } \\
\text { with worse cognitive performance, } \\
\text { probably reflecting the effect of } \\
\text { axonal subcortical damage and } \\
\text { myelin loss }\end{array}$ \\
\hline $\begin{array}{l}\text { Zivadinov } \\
\text { et al. } .^{52}\end{array}$ & $\begin{array}{c}\text { Evaluate if cognitive } \\
\text { deterioration in early stages } \\
\text { of MS correlates with brain } \\
\text { volume loss }\end{array}$ & $\begin{array}{l}53 \text { in early } \\
\text { disease } \\
\text { stages }\end{array}$ & $\begin{array}{l}\text { Extended } \\
\text { neuropsychologic } \\
\text { assessment }\end{array}$ & $\begin{array}{l}\text { Total brain volume } \\
\text { (semiautomatic } \\
\text { local program) }\end{array}$ & $\begin{array}{l}\text { In early stages of the disease, } \\
\text { cognitive deterioration correlated } \\
\text { signifcantly with total brain volume } \\
\text { loss probably due to axonal loss }\end{array}$ \\
\hline
\end{tabular}

RRMS: relapsing remitting multiple sclerosis; PVBC: percentage brain volume change. 
Table 4. Pivotal studies and the effect on brain atrophy and physical disability60.

\begin{tabular}{|c|c|c|c|c|c|c|}
\hline Year & Trial & Control arm & Treatment arm & $\mathrm{N}$ & $\begin{array}{l}\text { Brain volumen } \\
\text { measurement }\end{array}$ & $\begin{array}{l}\text { Effect of } \\
\text { atrophy * }\end{array}$ \\
\hline 1999 & MSCRG $^{61}$ & Placebo & $\mathrm{IFNb}-1^{\mathrm{a}} 6 \mathrm{MIU}$ & 301 & BPF & 0.50 \\
\hline 2006 & AFFIRM 62 & Placebo & Natalizumab & 942 & $\mathrm{BPF}$ & 0.56 \\
\hline 2006 & SENTINEL ${ }^{63}$ & IFNb-1a $30 \mathrm{Mcg}$ & IFNbeta 1-a 30 mcg + natalizumab 300 mg & 1171 & BPF & 0.77 \\
\hline 2008 & REGARD ${ }^{64}$ & GA & IFNbeta-1a-44 mcg & 764 & SIENA & 1.28 \\
\hline \multirow{2}{*}{2009} & \multirow{2}{*}{ BEYOND ${ }^{65}$} & \multirow{2}{*}{ GA } & IFNbeta-1a-250 & 1347 & \multirow{2}{*}{ SIENA } & 0.90 \\
\hline & & & IFNbeta-1a-500 & 1345 & & 0.80 \\
\hline \multirow{2}{*}{2010} & \multirow{2}{*}{ FREEDOMS ${ }^{58}$} & \multirow{2}{*}{ Placebo } & FTY $0.5 \mathrm{mg}$ & 843 & \multirow{2}{*}{ SIENA } & 0.63 \\
\hline & & & FTY $1.25 \mathrm{mg}$ & 847 & & 0.55 \\
\hline \multirow{2}{*}{2010} & \multirow{2}{*}{ CLARITY66 } & \multirow{2}{*}{ Placebo } & Cladribine 3.5 mg & 870 & \multirow{2}{*}{ SIENA } & 0.81 \\
\hline & & & Cladribine $5.25 \mathrm{mg}$ & 893 & & 0.81 \\
\hline \multirow{2}{*}{2011} & \multirow{2}{*}{ TEMSO 55} & \multirow{2}{*}{ Placebo } & Teriflunomide 7 mg & 728 & \multirow{2}{*}{$\mathrm{BPF}$} & 1.0 \\
\hline & & & Teriflunomide $14 \mathrm{mg}$ & 721 & & 1.0 \\
\hline \multirow{2}{*}{2012} & \multirow{2}{*}{ DEFINE ${ }^{56}$} & \multirow{2}{*}{ Placebo } & BG-12 240 mg t.i.d & 818 & \multirow{2}{*}{ SIENA } & 0.70 \\
\hline & & & BG-12 240 mg 3 daily & 824 & & 0.83 \\
\hline \multirow{3}{*}{2012} & \multirow{3}{*}{ CONFIRM ${ }^{57}$} & \multirow{3}{*}{ Placebo } & BG-12 240 mg t.i.d & 722 & \multirow{3}{*}{ SIENA } & 0.94 \\
\hline & & & BG-12 240 mg 3 daily & 708 & & 0.97 \\
\hline & & & $\mathrm{GA}$ & 713 & & 0.84 \\
\hline 2012 & MSCARE-| 67 & IFNbeta-1a & Alemtuzumab & 821 & BPF & 0.50 \\
\hline 2012 & MSCARE-II68 & IFNbeta-1a & Alemtuzumab & 1187 & $\mathrm{BPF}$ & 0.63 \\
\hline \multirow{2}{*}{2012} & \multirow{2}{*}{ FREEDOMS-I|69 } & \multirow{2}{*}{ placebo } & FTY $0.5 \mathrm{mg}$ & 757 & \multirow{2}{*}{ SIENA } & 0.70 \\
\hline & & & FTY $1.25 \mathrm{mg}$ & 757 & & 0.52 \\
\hline
\end{tabular}

GA: glatiramer acetate; ${ }^{*}$ The effect of atrophy is over physical disability at two years follow-up estimated as R2.

\section{IMPACT OF DISEASE MODIFYING THERAPIES ON BRAIN ATROPHY}

Based upon these findings, there is a clear need to identify medication not only for the inflammatory process but also for preventing brain atrophy progression and neurodegeneration. Currently, the effect of medication on MS and its secondary impact on brain atrophy is under investigation. However, in some phase III clinical trials the brain atrophy biomarker has become a primary assessment outcome.

In a study that included 519 patients with RRMS for a two-year period, the subcutaneous administration of interferon $b-1 a^{53}$, found no effect of treatment on brain atrophy when compared to placebo. In another study that used glatiramer acetate in the evaluation, there were no differences in brain atrophy during follow-up in the placebo $\mathrm{arm}^{54}$. In studies that used teriflunomoide no significant changes in brain atrophy were found when compared to the placebo arm, whereas in those studies that assessed fingolimod and BG-12 (FREEDOMS and TRANSFORMS and DEFINE studies) showed significant differences in atrophy rate reduction when compared with no treatment or active drug $55,56,57,58,59$. In a recent meta-analysis conducted by Sormani et al..$^{60}$, the researchers were able to demonstrate the impact of controlling degenerative activity with the current available MS treatments. This degenerative activity was reflected in the atrophy (Table 4). The main findings of the overall analysis showed that a greater reduction in brain atrophy led to reduced disability progression in the two-year follow-up period assessed ${ }^{60}$. Brain atrophy might also have a greater predictive value than conventional MRI findings in preventing physical disability progression (lesional load in T2).

\section{CONCLUSION}

In this review we describe the current available evidence regarding brain atrophy and its consequence in MS patients. MS has traditionally been considered a white matter inflammatory disease. Today, there is a large body of evidence that supports the hypothesis that gray matter involvement and the neurodegenerative mechanisms are at least partially independent from inflammation in this disease.

The neurodegenerative mechanism creates permanent damage and correlates with physical and cognitive disability. Therefore, it is important to treat MS in the early stages to decrease the loss of brain volume and its consequences. Some issues should be overcome in order to increase it's use and confidence, like the influence that brain water content could have on the measurement as well as the cut off value of annual brain atrophy that should be used in daily clinical practice for example. Regarding the first issue, many research lines addressed the issue and showed that the inclusion of pseudo T2 sequences as well as frequent MR scans can serve as a marker of changes in bulk brain water content and thus can help to investigate the presence of pseudoatrophy in multiple sclerosis vs. real brain volume loss in order to better characterize the 
temporal pattern of brain volume change in affected patients. The other issue mentioned is the cut off value in annual brain volume loss. De Stefano et al. demonstrates that different values of annual PBVC could define a pathological range at different levels of specificity (ie, 'pathological' rates could be defined as above $-0.52 \%$ with a specificity of $95 \%$, above $-0.46 \%$ with a specificity of $90 \%$ and above $-0.40 \%$ with a specificity of $80 \%$ ) and interestingly, increasing age did not influence in such cut-off values. Establishing cut-offs will allow to discriminate between physiological and pathological rates in patients with MS, however is currently a difficult task in MS.

Despite the relevance that brain volumetric has demonstrated, it's use has not yet being translated into clinical practice. However, advances in computational

technology are paving the way for a more disseminated use in MS as well as other neurological disorders.

\section{References}

1. Noseworthy JH, Lucchinetti C, Rodriguez M, Weinshenker BG. Multiple sclerosis. N Engl J Med. 2000;343(13):938-52. doi:10.1056/NEJM200009283431307

2. Trapp BD, Peterson J, Ransohoff RM, Rudick R, Mörk S, Bö L. Axonal transection in the lesions of multiple sclerosis. N Engl J Med. 1998;338(5): 278-85. doi:10.1056/NEJM199801293380502

3. De Stefano N, Airas L, Grigoriadis N, Mattle HP, O'Riordan J, Oreja-Guevara C et al. Clinical relevance of brain volume measures in multiple sclerosis. CNS Drugs. 2014;28(2):147-56. doi:10.1007/s40263-014-0140-z

4. Filippi M, Agosta F. Imaging biomarkers in multiple sclerosis. J Magn Reson Imaging. 2010;31(4):770-88. doi:10.1002/jmri.22102

5. Perez-Miralles F, Sastre-Garriga J, Tintore M, Arrambide G, Nos $\mathrm{C}$, Perkal $\mathrm{H}$ et al. Clinical impact of early brain atrophy in clinically isolated syndromes. Mult Scler. 2013;19(14):1878-86. doi:10.1177/1352458513488231

6. Rojas JI, Patrucco L, Míguez J, Besada C, Cristiano E. Brain atrophy in radiologically isolated syndromes. J Neuroimaging. 2015;25(1):68-71. doi:10.1111/jon.12182

7. Coleman MP, Perry VH. Axon pathology in neurological disease: a neglected therapeutic target. Trends Neurosci. 2002;25(10):532-37. doi:10.1016/S0166-2236(02)02255-5

8. Bjartmar C, Trapp BD. Axonal degeneration and progressive neurologic disability in multiple sclerosis. Neurotox Res. 2003;5(1-2):157-64. doi:10.1007/BF03033380

9. Craner MJ, Damarjian TG, Liu S, Hains BC, Lo AC, Black $J A$ et al. Sodium channels contribute to microglia/macrophage activation and function in EAE and MS. Glia. 2005;49(2):220-9. doi:10.1002/glia.20112

10. Evangelou N, Konz D, Esiri MM, Smith S, Palace J, Matthews PM. Size-selective neuronal changes in the anterior optic pathways suggest a differential susceptibility to injury in multiple sclerosis. Brain. 2001;124(9):1813-20. doi:10.1093/brain/124.9.1813

11. Simon JH. Brain atrophy in multiple sclerosis: what we know and would like to know. Mult Scler. 2006;12(6):679-87. doi:10.1177/1352458506070823

12. Filippi M, Absinta M, Rocca MA. Future MRI tools in multiple sclerosis.J Neurol Sci. 2013;331(1-2):14-8. doi:10.1016/j.jns.2013.04.025

13. Filippi M, Valsasina P, Rocca M. Magnetic resonance imaging of grey matter damage in people with MS. Int MS J. 2007;14(1):12-21.

14. Bermel RA, Bakshi R. The measurement and clinical relevance of brain atrophy in multiple sclerosis. Lancet Neurol. 2006;5(2):158-70. doi:10.1016/S1474-4422(06)70349-0

15. Paolillo A, Coles AJ, Molyneux PD, Gawne-Cain M, MacManus D, Barker GJ et al. Quantitative MRI in patients with secondary progressive MS treated with monoclonal antibody Campath $1 \mathrm{H}$. Neurology. 1999;53(4):751-7. doi:10.1212/WNL.53.4.751

16. Okuda DT, Siva A, Kantarci O, Inglese M, Katz I, Tutuncu $\mathrm{M}$ et al. Radiologically isolated syndrome: 5-year risk for an initial clinical event. PLoS One. 2014;9(3):e90509. doi:10.1371/journal.pone.0090509

17. De Stefano N, Stromillo ML, Rossi F, Battaglini M, Giorgio A, Portaccio E et al. Improving the characterization of radiologically isolated syndrome suggestive of multiple sclerosis. PLoS One. 2011;6(4):e19452. doi:10.1371/journal.pone.0019452

18. Di Filippo M, Anderson VM, Altmann DR, Swanton jk, Plant GT, Thompson AJ et al. Brain atrophy and lesion load measures over 1 year relate to clinical status after 6 years in patients with clinically isolated syndromes.J Neurol Neurosurg Psychiatry. 2011;81(2):204-8. doi:10.1136/jnnp.2009.171769

19. Filippi M, Rovaris M, Inglese M, Barkhof F, De Stefano N, Smith $S$ et al. Interferon beta-1a for brain tissue loss in patients at presentation with syndromes suggestive of multiple sclerosis: a randomised, double-blind, placebo-controlled trial. Lancet. 2004;364(9444):1489-96. doi:10.1016/S0140-6736(04)17271-1

20. Fisher E, Rudick RA, Simon JH, Cutter G, Baier M, Lee JC et al. Eight-year follow-up study of brain atrophy in patients with MS. Neurology. 2002;59(9):1412-20. doi:10.1212/01.WNL.0000036271.49066.06

21. Fisniku LK, Chard DT, Jackson JS, Anderson VM, Altmann DR, Miszkiel KA et al. Gray matter atrophy is related to long-term disability in multiple sclerosis. Ann Neurol. 2008;64(3):247-54. doi:10.1002/ana.21423

22. Sailer M, Fischl B, Salat D, Tempelmann C, Schönfeld MA, Busa E et al. Focal thinning of the cerebral cortex in multiple sclerosis. Brain. 2003;126(8):1734-44. doi:10.1093/brain/awg175

23. Jacobsen C, Hagemeier J, Myhr KM, Nyland H, Lode K, Bergsland $\mathrm{N}$ et al. Brain atrophy and disability progression in multiple sclerosis patients: a 10-year follow-up study. J Neurol Neurosurg Psychiatry. 2014;85(10):1109-15. doi:10.1136/jnnp-2013-306906

24. Hofstetter L, Naegelin Y, Filli L, Kuster P, Traud S, Smieskova $R$ et al. Progression in disability and regional grey matter atrophy in relapsing-remitting multiple sclerosis. Mult Scler. 2014;20(2):202-13. doi:10.1177/1352458513493034

25. Zivadinov R, Havrdová E, Bergsland N, Tyblova M, Hagemeier J, Seidl Z et al. Thalamic atrophy is associated with development of clinically definite multiple sclerosis. Radiology. 2013;268(3):831-41. doi:10.1148/radiol.13122424

26. Popescu V, Agosta F, Hulst HE, Sluimer IC, Knol DL, Sormani MP et al. Brain atrophy and lesion load predict long term disability in multiple sclerosis. J Neurol Neurosurg Psychiatry. 2013;84(10):1082-91. doi:10.1136/jnnp-2012-304094

27. Rojas JI, Patrucco L, Besada C, Bengolea L, Cristiano E. Brain atrophy at onset and physical disability in multiple sclerosis. Arq Neuropsiquiatr. 2012;70(10):765-8. doi:10.1590/S0004-282X2012001000003

28. Lukas C, Minneboo A, Groot V, Moraal B, Knol DL, Polman CH et al. Early central atrophy rate predicts 5 year clinical outcome in multiple sclerosis. J Neurol Neurosurg Psychiatry. 2010;81(12):1351-6. doi:10.1136/jnnp.2009.199968 
29. Horakova D, Dwyer MG, Havrdova E, Cox JL, Dolezal O, Bergsland $\mathrm{N}$ et al. Gray matter atrophy and disability progression in patients with early relapsing-remitting multiple sclerosis: a 5-year longitudinal study. J Neurol Sci. 2009;282(1-2):112-9. doi:10.1016/j.jns.2008.12.005

30. Fisher E, Lee JC, Nakamura K, Rudick RA. Gray matter atrophy in multiple sclerosis: a longitudinal study. Ann Neurol. 2008;64(3):255-65. doi:10.1002/ana.21436

31. Jasperse B, Vrenken H, Sanz-Arigita E, Groot V, Smith SM, Polman $\mathrm{CH}$ et al. Regional brain atrophy development is related to specific aspects of clinical dysfunction in multiple sclerosis. Neuroimage. 2007;38(3):529-37. doi:10.1016/j.neuroimage.2007.07.056

32. Charil A, Dagher A, Lerch JP, Zijdenbos AP, Worsley KJ, Evans AC. Focal cortical atrophy in multiple sclerosis: relation to lesion load and disability. Neuroimage. 2007;34(2):509-17. doi:10.1016/j.neuroimage.2006.10.006

33. Turner B, Lin X, Calmon G, Roberts N, Blumhardt LD. Cerebral atrophy and disability in relapsing-remitting and secondary progressive multiple sclerosis over four years. Mult Scler. 2003;9(1):21-7. doi:10.1191/1352458503ms868oa

34. Bakshi R, Benedict RH, Bermel RA, Jacobs L. Regional brain atrophy is associated with physical disability in multiple sclerosis: semiquantitative magnetic resonance imaging and relationship to clinical findings. J Neuroimaging. 2011;11(2):129-36. doi:10.1111/j.1552-6569.2001.tb00022.x

35. Amato MP, Hakiki B, Goretti B, Rossi F, Stromillo ML, Giorgio A et al. Association of MRI metrics and cognitive impairment in radiologically isolated syndromes. Neurology. 2012;78(5):309-14. doi:10.1212/WNL.0b013e31824528c9

36. Yaldizli O, Penner IK, Frontzek K, Naegelin Y, Amann M, Papadopoulou A et al. The relationship between total and regional corpus callosum atrophy, cognitive impairment and fatigue in multiple sclerosis patients. Mult Scler. 2013;20(3):356-64. doi:10.1177/1352458513496880

37. Rudick RA, Lee JC, Nakamura K, Fisher E. Gray matter atrophy correlates with MS disability progression measured with MSFC but not EDSS.J Neurol Sci. 2009;282(1-2):106-11. doi:10.1016/j.jns.2008.11.018

38. Cruz Gómez AJ, Ventura Campos N, Belenguer A, Ávila C, Forn C. Regional brain atrophy and functional connectivity changes related to fatigue in multiple sclerosis. PLoS One. 2013;8(10):e77914. doi:10.1371/journal.pone.0077914

39. Amato MP, Razzolini L, Goretti B, Stromillo ML, Rossi F, Giorgio A et al. Cognitive reserve and cortical atrophy in multiple sclerosis: a longitudinal study. Neurology. 2013;80(19):1728-33. doi:10.1212/WNL.0b013e3182918c6f

40. Batista S, Zivadinov R, Hoogs M, Bergsland N, Heininen-Brown M, Dwyer MG et al. Basal ganglia, thalamus and neocortical atrophy predicting slowed cognitive processing in multiple sclerosis. J Neurol. 2012;259(1):139-46. doi:10.1007/s00415-011-6147-1

41. Calabrese M, Rinaldi F, Grossi P, Mattisi I, Bernardi V, Favaretto A et al. Basal ganglia and frontal/parietal cortical atrophy is associated with fatigue in relapsing-remitting multiple sclerosis. Mult Scler. 2010;16(10):1220-8. doi:10.1177/1352458510376405

42. Pellicano C, Gallo A, Li X, Ikonomidou VN, Evangelou IE, Ohayon $\mathrm{JM}$ et al. Relationship of cortical atrophy to fatigue in patients with multiple sclerosis. Arch Neurol. 2010;67(4):447-53. doi:10.1001/archneurol.2010.48

43. Sumowski JF, Chiaravalloti N, Wylie G, Deluca J. Cognitive reserve moderates the negative effect of brain atrophy on cognitive efficiency in multiple sclerosis. J Int Neuropsychol Soc. 2009;15(4):606-12. doi:10.1017/S1355617709090912

44. Mineev KK, Prakhova LN, Il'ves AG, Kataeva GV, Petrov AM, Reznikova TN et al. Characteristics of neurological and cognitive status in patients with multiple sclerosis in relation to the location and volumes of demyelination foci and the severity of brain atrophy. Neurosci Behav Physiol. 2009;39(1):35-8. doi:10.1007/s11055-008-9086-2

45. Sanchez MP, Nieto A, Barroso J, Martín V, Hernández MA. Brain atrophy as a marker of cognitive impairment in mildly disabling relapsing-remitting multiple sclerosis. Eur J Neurol. 2008;15(10):1091-9. doi:10.1111/j.1468-1331.2008.02259.x

46. Houtchens MK, Benedict RH, Killiany R, Sharma J, Jaisani Z, Singh B et al. Thalamic atrophy and cognition in multiple sclerosis. Neurology. 2007;69(12):1213-23. doi:10.1212/01.wnl.0000276992.17011.b5

47. Tekok-Kilic A, Benedict RH, Weinstock-Guttman B, Dwyer MG, Carone D, Srinivasaraghavan B et al. Independent contributions of cortical gray matter atrophy and ventricle enlargement for predicting neuropsychological impairment in multiple sclerosis. Neuroimage. 2007;36(4):1294-300. doi:10.1016/j.neuroimage.2007.04.017

48. Tedeschi G, Dinacci D, Lavorgna L, Prinster A, Savettieri G, Quattrone A et al. Correlation between fatigue and brain atrophy and lesion load in multiple sclerosis patients independent of disability. J Neurol Sci. 2007;263(1-2):15-9. doi:10.1016/j.jns.2007.07.004

49. Sanfilipo MP, Benedict RH, Weinstock-Guttman B, Bakshi R. Gray and white matter brain atrophy and neuropsychological impairment in multiple sclerosis. Neurology. 2006;66(5):685-92. doi:10.1212/01.wnl.0000201238.93586.d9

50. Lazeron RH, Boringa JB, Schouten M, Uitdehaag BM, Bergers E, Lindeboom $\mathrm{J}$ et al. Brain atrophy and lesion load as explaining parameters for cognitive impairment in multiple sclerosis. Mult Scler. 2005;11(5):524-31. doi:10.1191/1352458505ms1201 oa

51. Edwards SG, Liu C, Blumhardt LD. Cognitive correlates of supratentorial atrophy on MRI in multiple sclerosis. Acta Neurol Scand. 2001;104(4):214-23. doi:10.1034/j.1600-0404.2001.00270.x

52. Zivadinov R, Sepcic J, Nasuelli D, De Masi R, Bragadin LM, Tommasi MA et al. A longitudinal study of brain atrophy and cognitive disturbances in the early phase of relapsing-remitting multiple sclerosis. J Neurol Neurosurg Psychiatry. 2001;70(6):773-80. doi:10.1136/jnnp.70.6.773

53. Paty DW, Li DK. Interferon beta-lb is effective in relapsing-remitting multiple sclerosis. II. MRI analysis results of a multicenter, randomized, double-blind, placebo-controlled trial. 1993 [classical article]. Neurology. 2001;57(12 Suppl 5):S10-5.

54. Rovaris M, Comi G, Rocca MA, Wolinsky JS, Filippi M. Short-term brain volume change in relapsing-remitting multiple sclerosis: effect of glatiramer acetate and implications. Brain. 2001;124(9):1803-12. doi:10.1093/brain/124.9.1803

55. O'Connor P, Wolinsky JS, Confavreux C, Comi G, Kappos L, Olsson TP et al. Randomized trial of oral teriflunomide for relapsing multiple sclerosis. N Engl J Med. 2011;365(14):1293-303. doi:10.1056/NEJMoa1014656

56. Gold R, Kappos L, Arnold DL, Bar-Or A, Giovannoni G, Selmaj $K$ et al. Placebo-controlled phase 3 study of oral BG-12 for relapsing multiple sclerosis. N Engl J Med. 2012;367(12):1098-107. doi:10.1056/NEJMoa1114287

57. Fox RJ, Miller DH, Phillips JT, Hutchinson M, Havrdova E, Kita M et al. Placebo-controlled phase 3 study of oral BG-12 or glatiramer in multiple sclerosis. N Engl J Med. 2012;367(12):1087-97. doi:10.1056/NEJMoa1206328

58. Kappos L, Radue EW, O'Connor P, Polman C, Hohlfeld R, Calabresi $P$ et al. A placebo-controlled trial of oral fingolimod in relapsing multiple sclerosis. N Engl J Med. 2010;362(5):387-401. doi:10.1056/NEJMoa0909494

59. Cohen JA, Barkhof F, Comi G, Hartung HP, Khatri BO, Montalban $X$ et al. Oral fingolimod or intramuscular interferon for relapsing multiple sclerosis. N Engl J Med. 2010;362(5):402-15. doi:10.1056/NEJMoa0907839 
60. Sormani MP, Arnold DL, De Stefano N. Treatment effect on brain atrophy correlates with treatment effect on disability in multiple sclerosis. Ann Neurol. 2014;75(1):43-9. doi:10.1002/ana.24018

61. Rudick RA, Fisher E, Lee JC, Simon J, Jacobs L. Use of the brain parenchymal fraction to measure whole brain atrophy in relapsing-remitting. Neurology. 1999;53(8):1698-704. doi:10.1212/WNL.53.8.1698

62. Polman $\mathrm{CH}$, O'Connor PW, Havrdova E, Hutchinson M, Kappos $\mathrm{L}$, Miller DH et al. A randomized, placebo-controlled trial of natalizumab for relapsing multiple sclerosis. N Engl J Med. 2006;354(9):899-910. doi:10.1056/NEJMoa044397

63. Rudick RA, Stuart WH, Calabresi PA, Confavreux C, Galetta SL, Radue EW et al. Natalizumab plus interferon beta-1a for relapsing multiple sclerosis. N Engl J Med. 2006;354(9):911-23. doi:10.1056/NEJMoa044396

64. Mikol DD, Barkhof F, Chang P, Coyle PK, Jeffery DR, Schwid SR et al. Comparison of subcutaneous interferon beta-1a with glatiramer acetate in patients with relapsing multiple sclerosis (the REbif vs Glatiramer Acetate in Relapsing MS Disease [REGARD] study): a multicentre, randomised, parallel, open-label trial. Lancet Neurol. 2008;7(10):903-14. doi:10.1016/S1474-4422(08)70200-X

65. O'Connor P, Filippi M, Arnason B, Comi G, Cook S, Goodin D et al. 250 microg or 500 microg interferon beta-1b versus 20 mg glatiramer acetate in relapsing-remitting multiple sclerosis: a prospective, randomised, multicentre study. Lancet Neurol. 2009;8(10):889-97. doi:10.1016/S1474-4422(09)70226-1

66. Giovannoni G, Comi G, Cook S, Rammohan K, Rieckmann P, Soelberg Sørensen P et al. A placebo-controlled trial of oral cladribine for relapsing multiple sclerosis. N Engl J Med. 2010;362(5):416-26. doi:10.1056/NEJMoa0902533

67. Cohen JA, Coles AJ, Arnold DL, Confavreux C, Fox EJ, Hartung $\mathrm{HP}$ et al. Alemtuzumab versus interferon beta $1 \mathrm{a}$ as first-line treatment for patients with relapsing-remitting multiple sclerosis: a randomised controlled phase 3 trial. Lancet. 2012;380(9856):1819-28. doi:10.1016/S0140-6736(12)61769-3

68. Coles AJ, Twyman CL, Arnold DL, Cohen JA, Confavreux C, Fox EJ et al. Alemtuzumab for patients with relapsing multiple sclerosis after disease-modifying therapy: a randomised controlled phase 3 trial. Lancet. 2012;380(9856):1829-39. doi:10.1016/S0140-6736(12)61768-1

69. Calabresi PA, Radue EW, Goodin D, Jeffery D, Rammohan KW, Reder AT et al. Safety and efficacy of fingolimod in patients with relapsing-remitting multiple sclerosis (FREEDOMS II): a double-blind, randomised, placebo-controlled, phase 3 trial. Lancet Neurol. 2014;13(6):545-56. doi:10.1016/S1474-4422(14)70049-3 